\title{
Integrazione dei dati acquisiti con sistemi image-based e range-based per una rappresentazione 3D efficiente
}

\author{
Fausta Fiorillo \\ Marco Limongiello \\ Cecilia Bolognesi
}

\section{Abstract}

Le tecnologie digitali hanno rappresentato un'occasione di innovazione e sviluppo in ambito rappresentativo durante i mesi di pandemia quando la comunicazione scientifica si è forzatamente costretta nei canali di comunicazione digitale.

II rilievo digitale, con l'integrazione di tecniche image-based e range-based consente di ottimizzare le misure sviluppate sul modello 3D e le relative rappresentazioni in ambito tecnico. Questo studio presenta l'analisi di una pipeline innovativa per integrare un dataset laser scanner direttamente all'interno della pipeline fotogrammetrica in un unico ambiente software. L'obiettivo principale è testare diverse procedure per l'allineamento e l'integrazione di nuvole di punti da sensori attivi (Terristrial Laser Scanner) e passivi (Fotogrammetria close-range). In particolare, sono state analizzati tre approcci: scala e roto-traslazione con Ground Control Point sfruttando il self-calibration bundle adjustment fotogrammetrico; integrazione dei panorami sferici delle singole stazioni laser nel flusso fotogrammetrico; script in Python per allineare la nuvola densa fotogrammetrica nel sistema di riferimento del TLS con una procedura ICP (Iterative Closest Point).

Lo studio presenta i primi risultati ottenuti per un caso studio a scala architettonica: il Mulino del Cantone, lungo il fiume Lambro nel Parco di Monza (MB). L'approccio integrato apre nuove opportunità per realizzare un rilievo 3D efficiente e una rappresentazione grafica completa.

Parole chiave

sensori attivi/passivi, laser scanning, fotogrammetria, approccio integrato, Cultural Heritage.

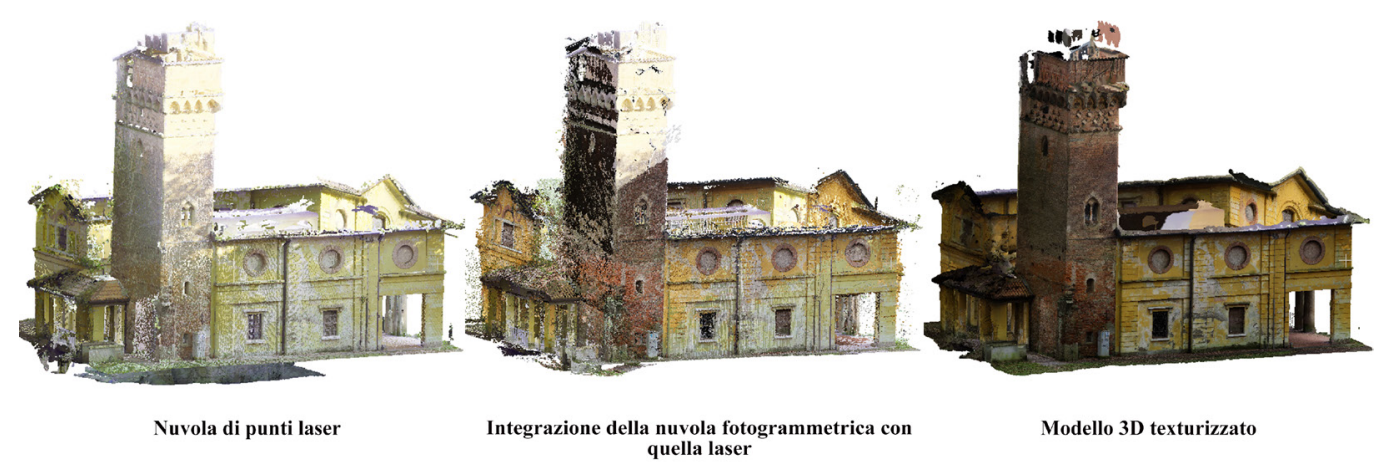




\section{Introduzione}

Le tecnologie digitali, sia di rilievo che di rappresentazione grafica, sono in continua evoluzione/innovazione, ed offrono prospettive di efficienti modalità di connessione e condivisione da remoto, tema di notevole interesse nell'ultimo anno 'in modalità a distanza'.

Nell'ambito del rilevo digitale, l'integrazione di tecniche range-based ed image-based consente di sfruttare i punti di forza di entrambi i sistemi, preformando le misure 3D e i relativi disegni tecnici [Remondino $20 \mathrm{ll}$ I]. Un approccio fotogrammetrico, infatti, garantisce una corrispondenza biunivoca tra i dati RGB del singolo pixel e le relative coordinate $X Y Z$, restituendo nello spazio 3D un modello geometrico e le relative informazioni radiometriche, ma anche immagini metriche e misurabili nello spazio 2D. Infatti uno dei vantaggi effettivamente utili alla rappresentazione tecnica di un edificio rilevato è la possibilità di generare orto-immagini delle facciate principali. D'altra parte, un sistema di scansione laser garantisce tempi di acquisizione più brevi in sito e un controllo più diretto ed efficace della geometria acquisita. Inoltre, la registrazione fra gli spazi esterni e quelli interni è più facile e veloce con un laser scanner terrestre (TLS-Terrestrial Laser Scanner), generalmente preferito in campo architettonico per misurare siti ampi, ambienti complessi o spazi interni.

Il vantaggio di un approccio integrato è che permette di sfruttare il potenziale di entrambe le tecniche per ottenere la migliore completezza e qualità delle rappresentazioni risultanti [Barba 20 19; Hassan 20 I 9; Florio 2020]. Lo svantaggio è la complessità della procedura per integrare i dati dei sensori attivi e passivi e la più complessa definizione di un flusso di lavoro efficiente. II tema è sempre stato di interesse nel panorama di ricerca internazionale [Beraldin 2004; Fassi 2007; Fassi 20I I] e sono state proposte diverse soluzioni [Adamopoulos 2017; Galli 2019; Luhmann 2019].

La ricerca presentata mira a definire una soluzione innovativa e una pipeline operativa per combinare nuvole di punti da più sensori (attivi e passivi). In particolare, lo studio presenta l'analisi di un possibile metodo per integrare dataset laser scanner direttamente nella pipeline fotogrammetrica all'interno di un unico ambiente software. L'approccio integrato apre nuove opportunità per ottenere un rilievo digitale efficiente e una rappresentazione grafica completa.

\section{Caso Studio}

Il caso studio scelto per effettuare le prove sperimentali è il Mulino del Cantone, un mulino ad acqua lungo il fiume Lambro nel Parco di Monza (MB), costruito a partire dal I 840. II progetto di Giacomo Tazzini (fig. I) sembra essere stato l'adattamento di un edificio preesistente che già conteneva una torretta medievale in mattoni [I] del XII secolo [Pelissetti 2009].
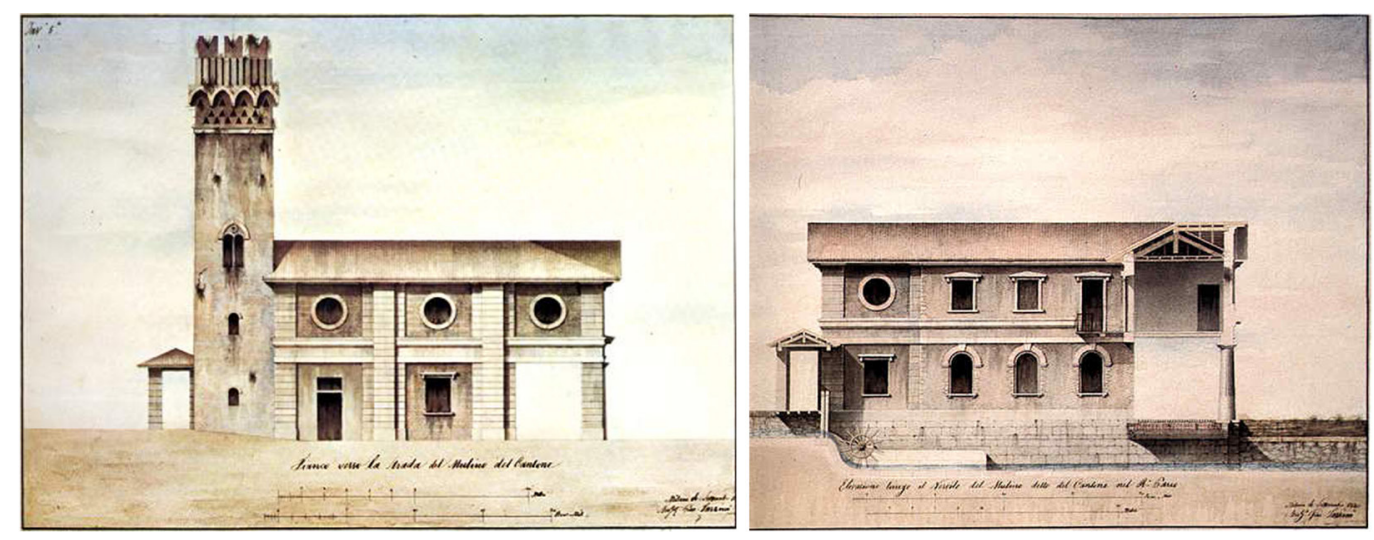
Nell'angolo nord del mulino, la piccola torre con merli ghibellini è stata volutamente lasciata incompleta in un ideale ed eterno stato di rovina secondo il gusto e la poetica romantica. La struttura originaria del mulino è costituita da pilastri in muratura, tamponatura in mattoni pieni intonacati, lasciati a vista solo nella torretta, solaio in legno e tetto a falde con manto di copertura in coppi. L'edificio, a pianta rettangolare con torretta a base quadrata, si articola su due livelli; il mulino occupa il piano terra, parallelo al corso del fiume.

Il prospetto sud di composizione eclettica, collega i due corpi di fabbrica laterali (sui lati est e ovest) con un porticato su colonne binate che nasconde le ruote delle macine azionate dal passaggio del canale d'acqua. II canale di derivazione (Roggia al Lambro) attraversa le due ali laterali.

Forma e dimensioni dell'edificio sono ideali per i test avendo dimensioni contenute e pianta regolare: la sala interna è circa $14 \mathrm{~m} \times 16 \mathrm{~m}$, il portico sulla facciata sud è circa $4 \mathrm{~m} \times 16 \mathrm{~m}$, la torre invece è circa $3 \mathrm{~m} \times 6 \mathrm{~m}$ con un'altezza massima di circa $20 \mathrm{~m}$. Queste caratteristiche fisiche hanno reso possibile un rilievo 3D basilare e veloce costituito da: I) poche scansioni essenziali (fig.2) per ricostruire metricamente la geometria della struttura; 2) acquisizioni di fotogrammetria terrestre delle quattro facciate esterne. In questo modo, i dati grezzi di rilievo, non essendo troppo pesanti, risultano facili da gestire durante gli esperimenti di elaborazione dei dati.

Fig. 2. Viste prospettiche dagli angoli sud-ovest e nord-est delle scansion allineate (a sinistra); a destra, una vista dall'alto delle stazioni TLS.
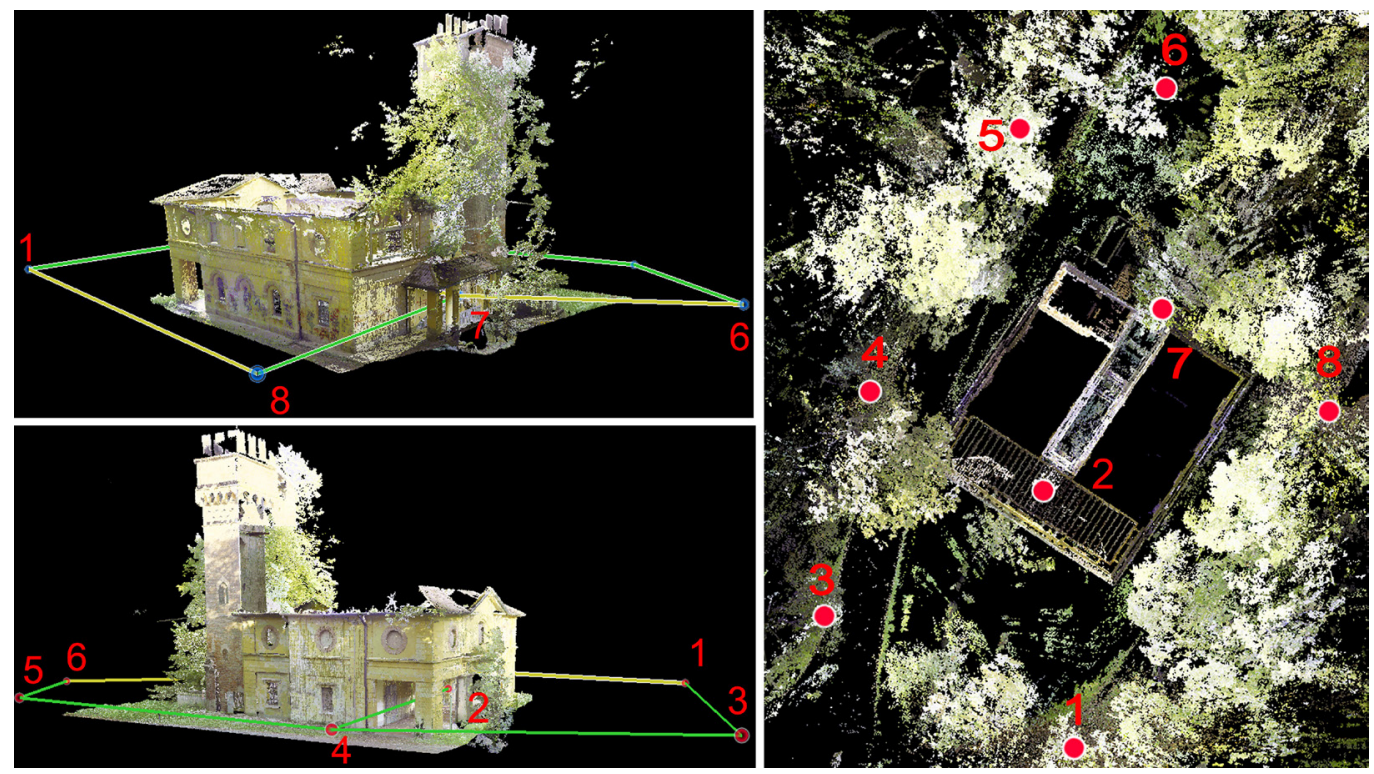

\section{Acquisizione ed elaborazione dei dati}

Allo scopo di rilevare le facciate principali esterne del mulino ad acqua, è stata effettuata un'acquisizione fotogrammetrica terrestre di tipo close-range con una Canon EOS 6D Mark II [2] dotata di un'ottica fissa con una focale di $24 \mathrm{~mm}$. I quattro prospetti sono stati acquisiti digitalmente catturando 58 immagini, scattando due foto per ogni stazione con una baseline media stimata di 3,20 m. La cattura dei fotogrammi, senza l'ausilio di markers, ha impiegato un lasso di tempo stimato in circa 15 minuti.

II laser scanner Leica RTC360 [3], invece, è stato utilizzato per l'esterno dell'edificio, il porticato e la galleria centrale (direzione nord-sud) dove transita il canale del fiume. Lo strumento è dotato di due sensori ottici: I) 3 camere HDR (5 esposizioni in bracketing) per l'acquisizione delle immagini sferiche a $360^{\circ}$;2) 5 telecamere per il tracciamento delle stazioni con il Visual Inertial System (VIS). Le camere HDR acquisiscono 36 foto (la singola con risoluzione $4000 \times 3000$ px) per ricostruire l'immagine panoramica utilizzata poi per colorare la singola nuvola di punti (valori RGB) (fig. 3). 
Fig. 3. Immagine panoramica in corrispondenza della stazione laser n.7 (in alto) e vista prospettica dall'angolo sud-est (a sinistra) e nord-ovest (a destra) della nuvola di punti colorata ottenuta dall'allineamento delle scansioni.
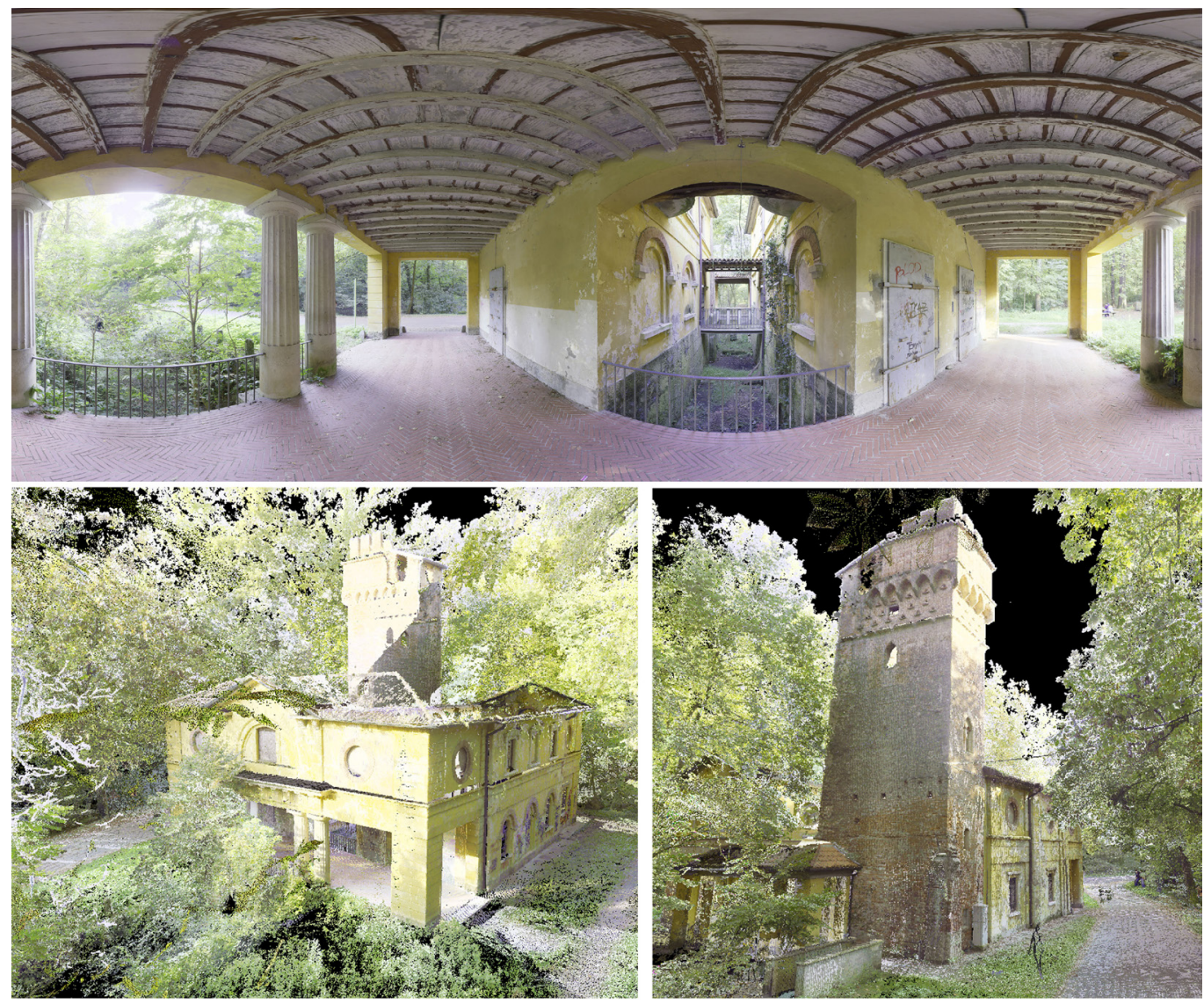

Una registrazione grezza in tempo reale tra le singole scansioni è ottenuta in sito grazie all'integrazione del VIS e della piattaforma IMU. IIVIS identifica alcune caratteristiche riconoscibili nello spazio circostante e le utilizza per tracciare le posizioni di scansione consecutive e ricostruire la traiettoria dello scanner. Questo approccio permette di ottimizzare i dati IMU e risolvere il problema degli errori di posizionamento [Higgins 20 I 8].

II rilievo TLS ha previsto 8 scansioni (6 stazioni per l'acquisizione delle facciate esterne e 2 per la galleria interna) (fig.2) con una risoluzione di $6 \mathrm{~mm}$ a $10 \mathrm{~m}$. Si è preferito utilizzare il numero minimo di scansioni essenzialmente per due motivazioni: ottenere dati non troppo grandi da elaborare durante gli esperimenti (maggiore gestibilità del progetto) e lavorare in una condizione limite.

L'acquisizione dei dati è stata eseguita in modalità target-less, mentre l'allineamento delle scansioni è stato ottimizzato mediante una registrazione cloud-to-cloud (basata sull'algoritmo ICP-Iterative Closest Point) nel software Cyclone REGISTER 360, eliminando preventivamente la vegetazione intorno alla struttura. La registrazione cloud-to-cloud ha stimato una deviazione media del gruppo di scansioni finale di circa $4 \mathrm{~mm}$ (con un valore massimo di $7 \mathrm{~mm}$ per una sola coppia di scansioni) con una sovrapposizione media tra le stazioni di presa di circa il 40\%. II modello finale allineato consente di estrarre le coordinate 3D di elementi architettonici riconoscibili utili per scalare e referenziare il progetto fotogrammetrico.

La ricerca mira a valutare l'integrazione di nuvole di punti provenienti da diversi sensori utilizzando il software Structure-from-Motion (SFM) Agisoft Metashape Professional [4]. Oltre all'allineamento (orientamento interno/esterno) e all'ottimizzazione delle coordinate oggetto (nuvola di punti sparsa), il software permette la generazione di nuvole di punti dense (semi-global matching), il meshing delle superfici e l'estrazione di ortofoto. L'aspetto innovativo della procedura presentata è l'importazione diretta del modello a nuvola di punti TLS all'interno del progetto fotogrammetrico. 


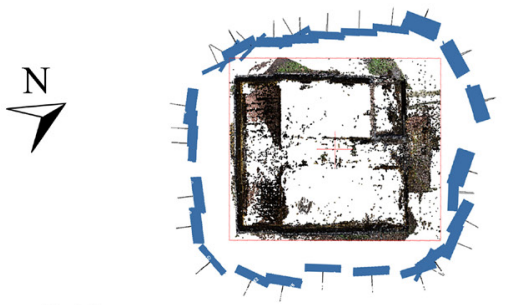

Test A
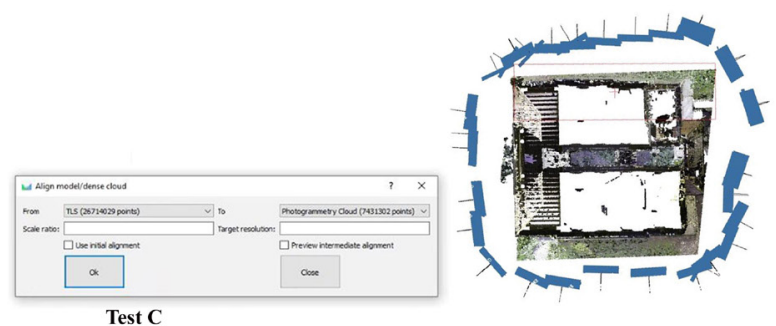

TLS Point Cloud

Test B

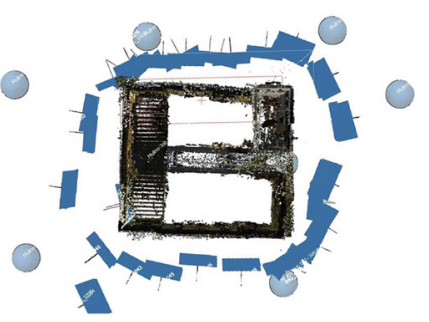

- Photogrammetry Point Cloud

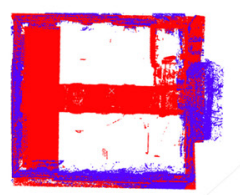

In particolare, sono stati analizzati e valutati tre diversi metodi di integrazione (fig. 4). A) La stima dei valori di traslazione, rotazione e fattore di scala utilizzando un self-calibrating bundle adjustment attraverso Ground Control Points (GCPs). B) L'integrazione dei datiTLS nel flusso di lavoro fotogrammetrico del progetto Metashape utilizzando i panorami sferici catturati dal laser scanner nelle singole stazioni. C) L'uso di uno script in Python (Metashape usa Python 3 come motore di scripting) per allineare indipendentemente la nuvola fotogrammetrica densa e il modello di punti TLS (con una buona sovrapposizione) attraverso una classica procedura ICP.

II test A ha seguito una pipeline fotogrammetrica standard per la fase di allineamento; i GCPs utilizzati sono stati misurati su punti architettonici naturali - ben visibili in entrambi i rilievi - direttamente dal modello finale TLS allineato in Cyclone Register 360. Per il calcolo del self-calibrating bundle adjustment, sono stati inclusi 16 GCPs (4 per ogni prospetto), stimando un RMSE di 3,2 cm. Per mezzo della procedura illustrata, le due nuvole di punti sono nello stesso sistema di riferimento locale e possono essere unite per le successive elaborazioni (generazione di modelli poligonali, creazione di mesh texurizzate ed estrazione di ortofoto).

Nel test B, l'integrazione di dataset di sensori attivi e passivi è realizzata con un approccio diverso. I panorami sferici catturati dalle singole stazioni laser scanner sono importati ed elaborati nello stesso progetto Metashape utilizzato per le acquisizioni di fotogrammetria close-range. In primis, si è resa necessaria la conversione dei dati strutturati del laser dal formato raw a quello supportato dal software (E57 o PTS). II software utilizza la procedura standard di corrispondenza tra immagini fotogrammetriche per registrare le foto e i panorami laser in uno stesso chunk.

I punti omologhi tra le immagini e le scansioni laser sono identificati durante la fase di allineamento delle immagini. I Tie point calcolati sono utilizzati per triangolare durante il bundle adjustment le posizioni delle camere e le posizioni del laser scanner nello stesso sistema di riferimento. Con questa procedura, l'allineamento delle scansioni TLS viene realizzato implementando gli algoritmi di SfM tra le immagini panoramiche del laser; di conseguenza, la precisione di allineamento - tra le singole scansioni - calcolata nell'elaborazione del software TLS viene invalidata.

Se la registrazione delle scansioni TLS è affidabile e precisa, è possibile preservare il suo allineamento ed evitare la procedura di corrispondenza delle immagini panoramiche e fotografiche. In questo caso, si consiglia di allineare prima le immagini fotogrammetriche e poi importare i panorami sferici del laser nello stesso chunk ed eventualmente eseguire uno specifico script Python [5]. È necessario che l'orientamento esterno delle immagini e i dati del TLS siano nel medesimo sistema di riferimento per essere correttamente elaborati insieme. 
Per la nostra analisi, preferiamo questa seconda pipeline che utilizza l'orientamento delle scansioni TLS come riferimento così da ottenere un allineamento più efficiente tra $\mathrm{i}$ due dataset. In particolare, abbiamo utilizzato le stesse coordinate dei GCPs della nuvola TLS del test $A$.

Infine, nel test C, la nuvola TLS allineata (non le singole scansioni) viene importata direttamente all'interno del progetto fotogrammetrico per ottimizzare la nuvola fotogrammetrica attraverso una procedura ICP. Per velocizzare la procedura, come nei test A e B, i due modelli vengono allineati nello stesso sistema di riferimento utilizzando le coordinate dei GCPs selezionati. Dopo aver eseguito lo script Python, la procedura automatica utilizza una libreria open-source [6] che supporta strutture dati e algoritmi in C++ e Python per software con dati 3D.

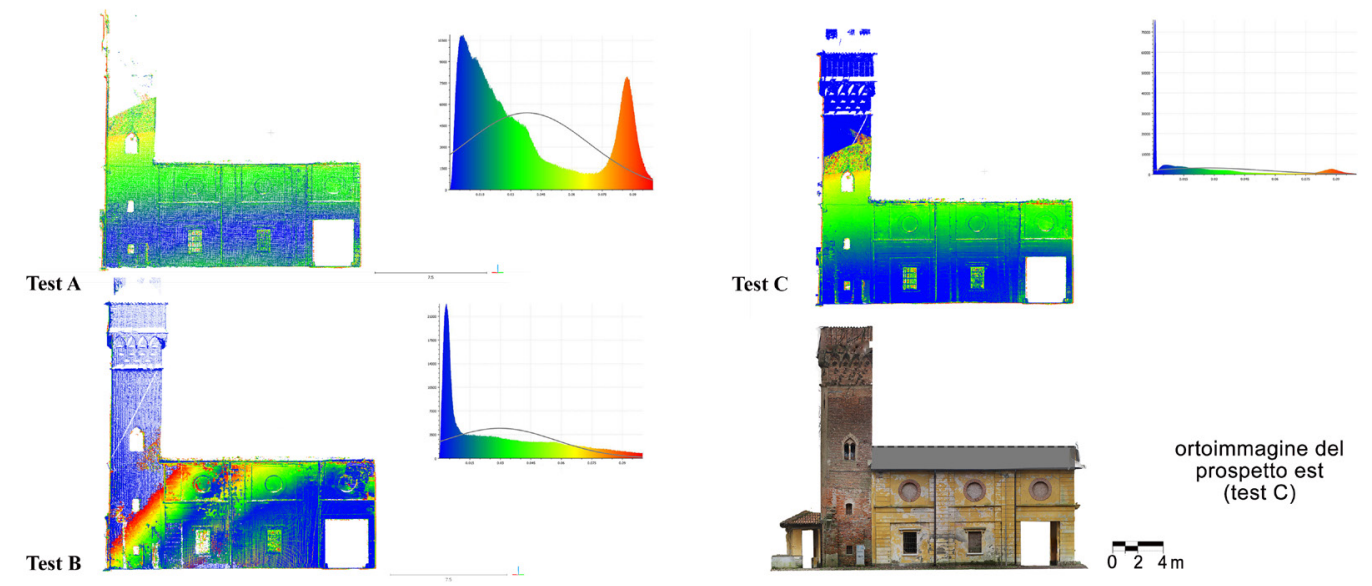

\section{Analisi dei risultati}

Una prima analisi sviluppata è stata il confronto diretto [7] tra la nuvola di punti TLS e i modelli prodotti nei test A, B e C; in generale tutti i confronti implementati utilizzano come riferimento fisso il modello finale del laser scanner.

Per la rappresentazione del confronto metrico, si è scelto il prospetto con la torre (prospetto nord del mulino) che introduce note difficoltà relazionate all'altezza. Nella figura 5, tracciando le distanze su una scala comune di $0-10 \mathrm{~cm}$, si può osservare che l'output del test $\mathrm{A}$ presenta una distribuzione più ampia delle distanze, a differenza delle distribuzioni dei test $\mathrm{B}$ e $\mathrm{C}$ che presentano un picco per le distanze nuvola-nuvola inferiore a $5 \mathrm{~mm}$.
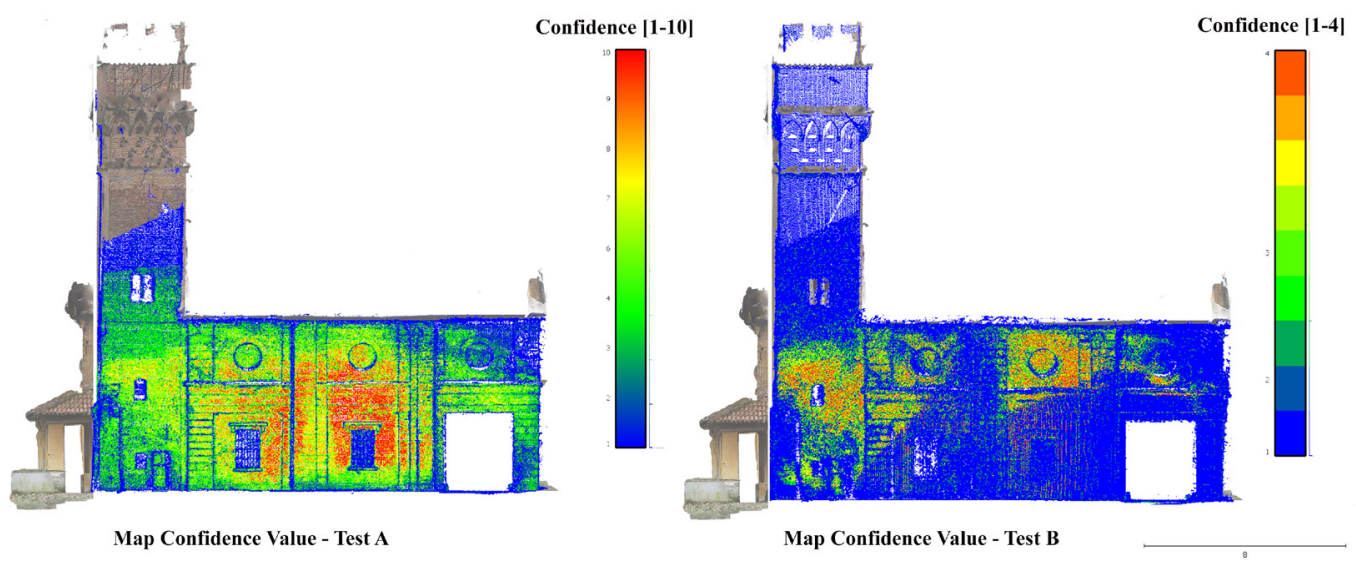

Map Confidence Value - Test B 
Pertanto, la sola rototraslazione eseguita utilizzando punti omologhi, calcolati anche successivamente come GCPs nella procedura di bundle adjustment, ha prodotto deviazioni maggiori (test A). Queste deviazioni aumentano anche in altezza, o genericamente, sono maggiori all'aumentare della distanza del punto 3D dalla stazione TLS e dalle prese fotogrammetriche. Questa tendenza può essere osservata anche per i test B e C.

Il test $B$, con l'inserimento delle immagini sferiche del TLS, presenta una mappa di deviazioni tipiche di un disallineamento; probabilmente, i panorami sferici producono un errato allineamento per le proiezioni dei punti 3D. Per questo test, si è osservata una correlazione tra le deviazioni nuvola-nuvola e il valore 'Confidence', calcolato in Metashape; questo parametro dipende da quante mappe di profondità sono state utilizzate per generare il punto 3D (fig. 6). L'errato posizionamento delle immagini sferiche nello spazio 3D produce anche una falsa proiezione utilizzando le mappe di profondità nella nuvola densa.

Infine, il test $C$ è il caso con picco e deviazione media più bassi rispetto agli altri test. In particolare, come già osservato in altri studi, il posizionamento delle nuvole di punti nello stesso sistema di riferimento e ha accelerato il processo che converge in poche iterazioni grazie all'implementazione dell'algoritmo ICP.

\section{Conclusioni}

Questo articolo presenta i primi risultati relativi all'integrazione di dataset di sensori attivi e passivi, applicati a un caso di studio su piccola scala architettonica, il Mulino del Cantone. L'obiettivo principale dello studio è stato di testare diverse procedure per l'allineamento e l'integrazione di nuvole di punti TLS e fotogrammetriche e di fornire una prima valutazione metrica.

La procedura implementata evidenzia due distinti vantaggi. I due sistemi possono essere combinati per completare un rilievo 3D nel modo più veloce ed efficiente. In particolare, la scansione laser può essere utilizzata per misurare geometrie complesse e spazi interni (dove generalmente sono presenti maggiori problemi di illuminazione). La fotogrammetria invece può essere vantaggiosa se utilizzata per gli esterni, soprattutto se esiste la possibilità di acquisire immagini aeree e produrre orto-immagini efficaci dei prospetti [Russo e Manfredini 20I4; Achille et al. 20 I5; Repola et al. 2019].

Ovviamente, ci sono anche casi in cui sarebbe preferibile l'opposto, se ad esempio l'interno dell'edificio è affrescato, e/o l'esterno si trova in un centro abitato con strade molto strette dove non è possibile utilizzare un drone. Nel contesto analizzato, l'integrazione con i dati TLS permette anche di misurare e rappresentare le zone più alte difficilmente rilevabili da un'acquisizione fotogrammetrica terrestre come ad esempio per la torre del mulino (fig. 7). Tra i vari test, l'implementazione di un algoritmo ICP (test C) risulta essere la procedura che ottimizza le distanze tra le nuvole di punti e quindi il reciproco allineamento.

L'inserimento del flusso di lavoro SfM delle immagini panoramiche acquisite da TLS, insieme alle foto terrestri (o UAV), può permettere l'integrazione delle nuvole di punti e la loro successiva fusione, proiettando dalle mappe di profondità (delle immagini sferiche e fotogrammetriche) i punti 3D per generare la nuvola densa. In questo caso (test B), la precisione dell'integrazione testata è inferiore. Tuttavia, questo tipo di soluzione risulta rapida, soprattutto quando l'interno è misurato conTLS (generalmente per mancanza di luce e per ridurre i tempi di acquisizione) mentre l'esterno con la sola fotogrammetria. È bene ricordare che per la buona riuscita dell'allineamento, deve sempre esserci una buona percentuale di sovrapposizione tra i due rilievi.

In ogni caso, i requisiti cruciali per una corretta integrazione del dataset sono la presenza di sovrapposizioni tra le nuvole di punti e un numero adeguato di punti di controllo ben visibili in entrambi. Ulteriori esperimenti sono previsti per il futuro, includendo immagini da drone e una rete più estesa di stazioni laser (compresi gli interni). Inoltre, si vorrebbe verificare per lo stesso set di dati, differenti soluzioni software SfM per confrontare pipeline e risultati. 
Fig. 7. Orto-immagini del test C: prospetti sud (sinistra) e ovest (destra)
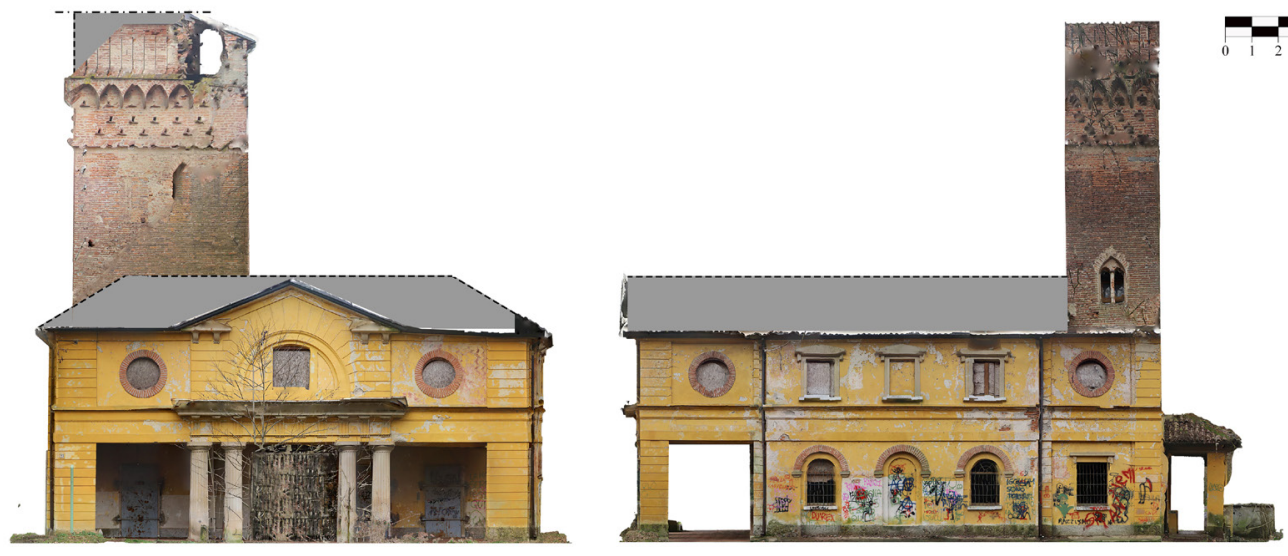

Note

[I] La torretta medievale è probabilmente l'unico resto dell'antico fronte protettivo di Monza, collegato alle strutture preesistenti della vicina Villa Mirabello. <https://it.wikipedia.org/wiki/Mulino_del_Cantone> (consultato il 26 febbraio 202I).

[2] Sensore Full-Frame CMOS, 6240×4I60 px, pixel size di $5.75 \mu \mathrm{m}$.

[3] Specifiche tecniche: velocità di acquisizione fino a 2 milioni di punti al secondo, campo di lavoro 0,5-130m, FOV di 360 (base rotante orizzontale) $\times 300^{\circ}$ (specchio rotante verticale), e noise range stimato di $4 \mathrm{~mm}$ a $10 \mathrm{~m}$.

[4] Versione I.7I in cui sono stati recentemente inclusi strumenti per integrare e gestire dati laser

[5] <https://github.com/agisoft-Ilc/metashape-scripts/blob/master/src/quick_layout.py> (consultato il 26 febbraio 202 I).

[6] Open3D è rilasciato come open-source sotto la licenza MIT ed è disponibile al link <http://www.open3d.org> (consultato il 26 febbraio 2021 )

[7] Funzione Cloud/Cloud-Distance del software open-source CloudCompare. <https://www.danielgm.net/cc/> (consultato il 26 febbraio 2021)

\section{Riferimenti bibliografici}

Achille C. et al. (20 I5). UAV-Based Photogrammetry and Integrated Technologies for Architectural Applications - Methodological Strategies for the After-Quake Survey of Vertical Structures in Mantua (Italy). In Sensors, n. I 5/7, pp. I5520- I 5539.

Adamopoulos E., (2017). Multi-sensor documentation of metric and qualitative information of historic stone structures. In Int Arch. Photogramm. Remote Sens. Spatial Inf. Sci, n. IV-2/W2, pp. I-8.

Barba S. et al. (2019). Integration of active sensors for geometric analysis of the chapel of the Holy Shroud. In Int. Arch. Photogramm. Remote Sens. Spatial Inf. Sci., n. XLII-2MI5, pp. I49-I56.

Beraldin J.A. (2004). Integration of laser scanning and close-range photogrammetry - The last decade and beyond. In AA.VV. Proceedings of the XXth ISPRS Congress, vol. 35, pp. I2-23.

Fassi F. (2007). 3D modeling of complex architecture integrating different techniques - a critical overview. In Int. Arch. Photogramm. Remote Sens. Spatial Inf. Sci, n. 36, pp.?????

Fassi F., Achille C., Fregonese L. (201 I). Surveying and modelling the main spire of Milan Cathedral using multiple data sources In The Photogrammetric Record, n. 26, pp. 462-487.

Florio R. et al. (2020). Architettura archeologia per il rilievo integrato, il caso esemplare di Cuma: le Terme del Foro. In Arena A. et al. (a cura di), Connettere. Un disegno per annodare e tessere. Atti del $42^{\circ}$ Convegno Internazionale dei Docenti delle Discipline della Rappresentazione/Connecting. Drawing for weaving relationships. Proceedings of the 42th International Conference of Representation Disciplines Teachers, pp. 2 I 82-2203. Milano: FrancoAngeli.

Galli M. et al. (2019). Rappresentare il visibile e conoscere il non visibile: studi sulla Basilica lulia al Foro Romano. In Belardi P. (a cura di), Riflessioni l'Arte del Disegno/ll Disegno dell'Arte. Atti del $41^{\circ}$ convegno internazionale dei docenti delle discipline della rappresentazione congresso della Unione Italiana per il Disegno. Roma: Gangemi, pp. 667-674.

Hassan A.T., Fritsch D. (2019). Integration of Laser Scanning and Photogrammetry in 3D/4D Cultural Heritage Preservation - A Review. In International Journal of Applied Science and Technology, n. 9/4, pp. 76-91.

Higgins S. (June 14, 2018). Leica's RTC 360 lidar scanner registers your point clouds automatically, in real time, in the field. In SPAR3D. <https://www.spar3d.com/news/lidar/leicas-rtc360-lidar-scanner-registers-your-point-clouds-automatically-in-realtime-in-the-field/> (consultato il 26 febbraio 202I)

Luhmann T. (2019). Combination of Terrestrial Laserscanning, Uav and Close-Range Photogrammetry for 3D Reconstruction of Complex Churches in Georgia. In Int. Arch. Photogramm. Remote Sens. Spatial Inf. Sci., n. XLII-2M I I, pp. 753-76I. 
Pelissetti L. S. (2009). II parco di Monza. Itinerari storico-naturalistici. Missaglia (LC): Bellavite.

Remondino, F. (20I I). Heritage Recording and 3D Modeling with Photogrammetry and 3D Scanning. In Remote Sensing, n. 3/6, pp. I I04-1 I38.

Repola L. (2019). La rappresentazione quale specchio del reale: le nuove tecnologie a servizio della conoscenza per la documentazione di ambienti complessi. In Belardi P. (a cura di), Riflessioni l'Arte del Disegno. Atti del $41^{\circ}$ convegno internazionale de docenti delle discipline della rappresentazione congresso della Unione Italiana per il Disegno. Roma: Gangemi, pp. 96 I-968.

Russo M., Manfredini A. M. (20I4). Metodiche integrate di rilievo 3D per l'analisi di architetture complesse. II caso dell'abbazia di Pomposa. In Giandebiaggi P.,Vernizzi C. (a cura di). Italian Survey \& International Experience. $36^{\circ}$ Convegno Internazionale dei Docenti della Rappresentazione. Roma: Gangemi, pp. 989-998.

\section{Sitografia}

Agisoft Helpdesk Portal, 8/2/202I. Terrestrial laser scanning data processing. <https://agisoft.freshdesk.com/support/solutions/ articles/3 I000 I59 I0 I-terrestrial-laser-scanning-data-processing> (consultato il 26 febbraio 202 I).

I| Molino del Cantone ( 1899). <https://arengario.net/nelp/cartp08.html> (consultato il 26 febbraio 202 I).

La chiusa del Cantone. <https://arengario.net/nelp/cartp24.html> (consultato il 26 febbraio 202I).

SIRBeC scheda ARL - MI230-00102

<http://www.lombardiabeniculturali.it/architetture/schede/MI230-00 I02/> (consultato il 26 febbraio 202 I).

\section{Autori}

Fausta Fiorillo, Politecnico di Milano, fausta.fiorillo@polimi.it

Marco Limongiello, Università degli Studi di Salerno, mlimongiello@unisa.it

Cecilia Bolognesi, Politecnico di Milano, cecilia.bolognesi@polimi.it

Per citare questo capitolo: Fiorillo Fausta, Limongiello Marco, Bolognesi Cecilia (2021). Integrazione dei dati acquisiti con sistemi image-based e range-based per una rappresentazione 3D efficiente/lmage-Based and Range-Based Dataset Integration for an Efficient 3D Representation -In Arena A Arena M Mediati D. Raffa P (a cura di) Connettere Un disegno per annodare e tessere Linguogoi Distanze Tecnologie Atti del $42^{\circ}$ Convegno Internazionale dei Docenti delle Discipline della Rappresentazione/Connecting. Drawing for weaving relationship. Languages Distances Technologies. Proceedings of the 42th International Conference of Representation Disciplines Teachers. Milano: FrancoAngeli, pp. 2319-2336. 


\title{
Image-Based and Range-Based Dataset Integration for an Efficient 3D Representation
}

\author{
Fausta Fiorillo \\ Marco Limongiello \\ Cecilia Bolognesi
}

\section{Abstract}

Digital technologies provided an opportunity for innovation and development in the graphic representation field during the pandemic when scientific communication was forced into digital communication channels.

The digital survey with the image-based and range-based techniques integration allows optimizing 3D measurements and the related technical representations. This study presents the analysis of an innovative pipeline to integrate the Terrestrial Laser Scanner (TLS) dataset directly into the photogrammetric pipeline within a single software environment. The main objective was to test different procedures for the alignment and integration of point clouds from active (TLS) and passive (close-range photogrammetry) sensors and provide a first metric evaluation.

In particular, three methods were analyzed: scale and roto-translation with Ground Control Points through the photogrammetric self-calibration bundle adjustment; integration of the spherical panoramas by the single laser stations into the photogrammetric workflow; Python script to align the photogrammetric dense cloud in the TLS reference system through an Iterative Closest Point (ICP) procedure.

The study presents the first results applied to a small architectural scale case study: the Mulino del Cantone, a watermill along the Lambro river in the Park of Monza (MB). The mixed approach opens new opportunities to achieve an efficient 3D survey and a complete graphic representation.

\section{Keywords}

active/passive sensor, laser scanning, photogrammetry, multi-sensor dataset integration, cultural heritage.

Raw digital models of the Mulino del Cantone, from left to right: from left to right: and photogrammetry integrations; textured mesh model.

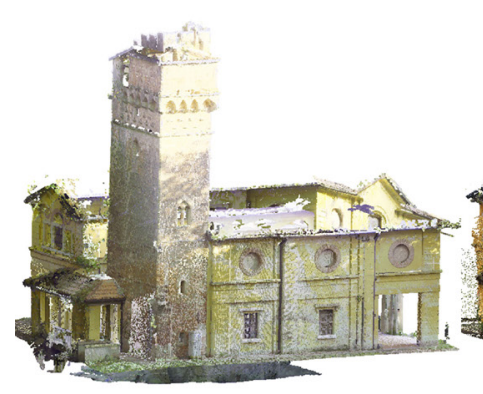

Laser Scanning Point Cloud

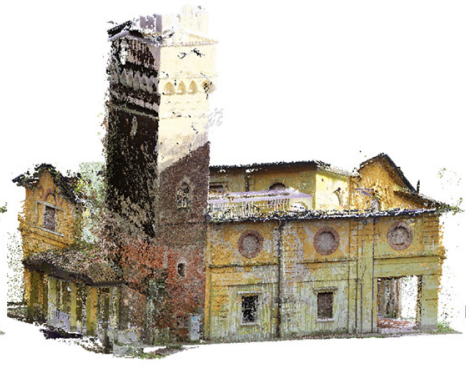

Integrated Point Clouds

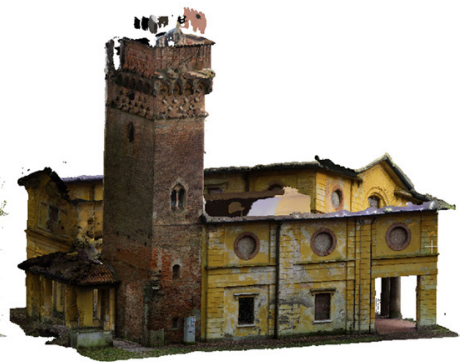

Textured 3D Models 


\section{Introduction}

Digital technologies, both survey and graphic representation, are in continuous evolution/innovation and prospects of efficient mode for remote connection and sharing, considerable interest topic in the last year 'in distance mode".

In the digital survey field, the integration of image-based and range-based techniques allows taking advantage of the strengths of both systems optimizing the 3D measurements and related technical drawings [Remondino $20 \mathrm{ll}$ ]. A photogrammetric approach ensures a direct one-to-one correspondence between the RGB data of a single-pixel and the related $X Y Z$ coordinates. It indeed provides in the 3D space the geometrical model and its radiometric information, but also metric and measurable images. One of the advantages useful for the technical representation of a surveyed building is the possibility of generating ortho-images of the main facades. On the other hand, a laser scanner system ensures shorter acquisition times on-site and more straightforward and more effective control of the captured geometry. Moreover, the alignment between outdoor and indoor spaces measurements is easier and quicker with a Terrestrial Laser Scanner (TLS), which is generally preferred in the architectural field to measure large areas, complex environments or interior spaces.

The advantage of an integrated approach is that it can use the potential of both techniques to achieve the best completeness and best quality of the resulting representations [Barba 2019; Hassan 2019; Florio 2020]. The disadvantage is the complexity of the procedure to integrate data from the active and passive sensors and the more complex definition of an efficient workflow. The well-known topic has always been of interest in the international research panorama [Beraldin 2004; Fassi 2007; Fassi 20I I] and different solutions have been provided [Adamopoulos 20 17; Galli 2019; Luhmann 2019].

This research aims to define an innovative solution and an operative pipeline to combine point clouds from several sensors (active and passive). In particular, the study presents the analysis of a possible method to integrate terrestrial laser scan dataset directly into the photogrammetric pipeline within a single software environment. The mixed approach opens new opportunities to achieve an efficient 3D digital survey and a complete graphic representation.

\section{Case study}

The case study chosen to carry out the experimental tests is the Mulino del Cantone, a watermill along the Lambro river in the Park of Monza (MB), built starting in 1840. The Giacomo Tazzini's project (fig. I) seems to have been the adaptation of a pre-existing building that already contained a medieval brick turret [I] of the XII century [Pelissetti 2009]. In the
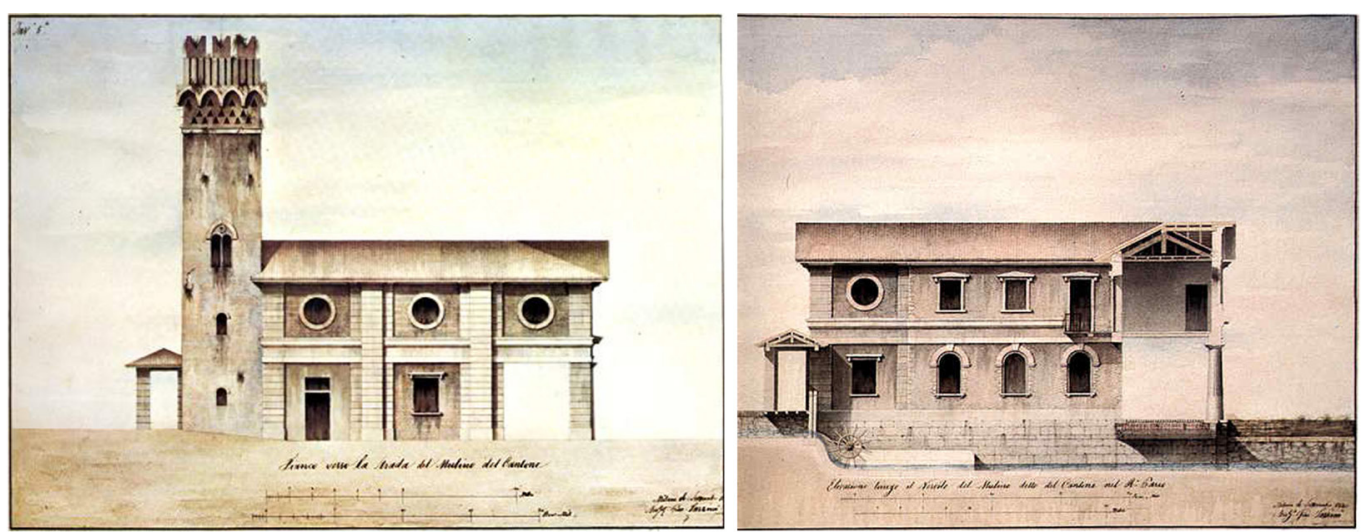
northern mill corner, the small tower with crenellation (Ghibelline merlons) was intentionally left incomplete in an ideal and eternal state of ruin according to romantic poetics.

The original watermill structure comprises masonry pillars, solid brick walls plastered, left exposed in the turret, wooden beam floor and a pitched roof with a roof covering in tiles. The building, based on a rectangular plan with a square-based turret, has two levels. The mill occupies the ground floor plan, parallel to the course of the river.

The south elevation of eclectic composition connects the two lateral structures (on the east and west sides) with a colonnade on coupled columns that hides the millstones wheels activated by the water channel passage. The derivation canal (Roggia al Lambro) cross the two lateral wings.

The shape and dimension of the building are ideal for the tests: it is a not too big with a regular rectangular layout. The inner room is about $14 \mathrm{~m} \times 16 \mathrm{~m}$, the portico on the south facade is about $4 \mathrm{~m} \times 16 \mathrm{~m}$, and the tower has a rectangular base of about $3 \mathrm{~m} \times 6 \mathrm{~m}$ and a maximum height of about $20 \mathrm{~m}$. These physical characteristics made it possible a basic and quick 3D survey consisting of: I) a few essential scans (fig. 2) to metrical reconstruct the structure geometry; 2) terrestrial photogrammetric acquisitions of the four external facades. This way, the digital survey raw data was not too big and easy to manage during data processing experiments.

Fig. 2. Perspective views from the Southwest and Northeast corners of the aligned scans (on the left),
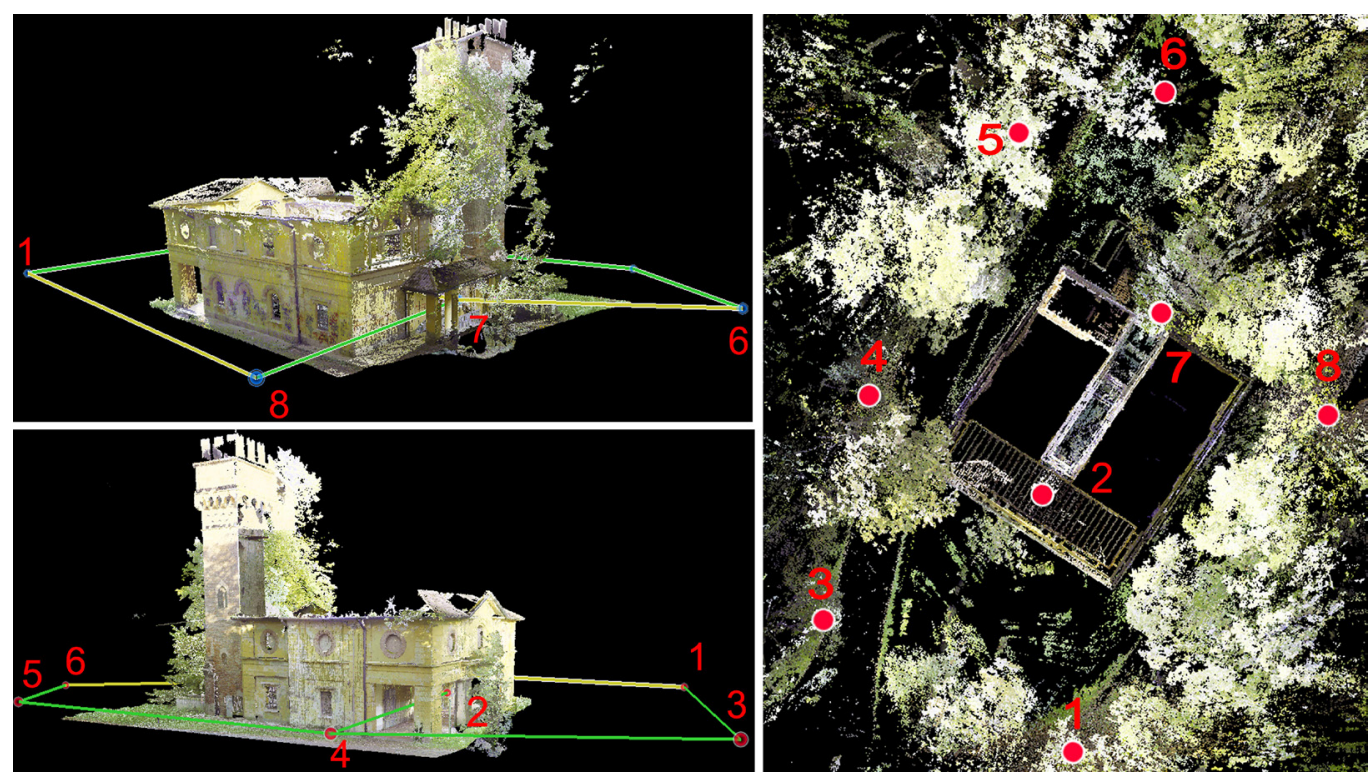

\section{Data acquisition and processing}

A close-range terrestrial photogrammetric acquisition was carried out with a Canon EOS 6D Mark II [2] and a fixed lens with a focal of $24 \mathrm{~mm}$ to survey the watermill external walls. The four exterior elevations were digitally captured with 58 images, taking two photos for each station with an estimated average baseline of $3.20 \mathrm{~m}$. The acquisition was quick (without markers) taking approximately I 5 minutes.

Instead, a TLS Leica RTC360 [3] was used to 3D measure of the building outer profile, the colonnade and the centerline gallery (north-south direction) where the river channel pass. The instrument is equipped with two optical sensors: I) 3 HDR cameras (5 bracketing exposures) for the $360^{\circ}$ spherical image capturing; 2) 5 cameras for the motion tracking of the Visual Inertial System (VIS). The HDR cameras acquire 36 photos (single capture with a resolution of $4000 \times 3000$ pixels) to reconstruct the panoramic image used to colored the single point cloud (RGB values) (fig. 3).

A real-time on-site raw registration among the single scans is achieved thanks to the VIS and the IMU platform integration. The VIS identifies some recognizable features in the space 
Fig. 3. Spherical image captured by TLS station n. 7 (on the bottom) and the perspective view from the Southeast (on the left) and Northwest (on the right) corner of the final colored point cloud formed by the aligned scans.
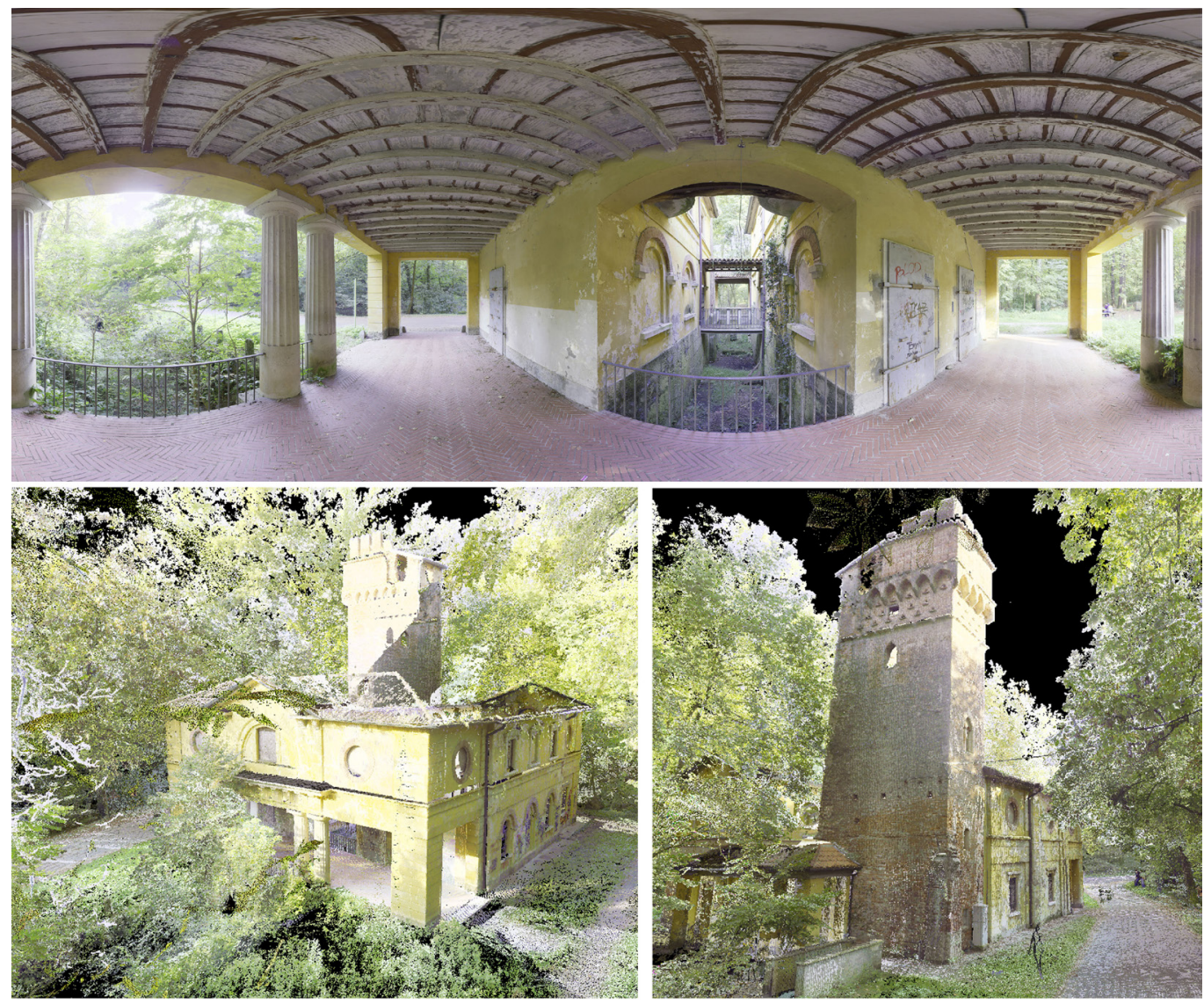

and uses them to track the consecutive scan locations and reconstruct the scanner path. This approach allows optimizing the IMU data and solving the problem of positing errors [Higgins 20l8].

The TLS survey included eight scans ( 6 stations for the acquisition of the external facades and 2 for the internal gallery) (fig. 2) with a resolution of $6 \mathrm{~mm}$ at $10 \mathrm{~m}$. We preferred to use the minimum number of scans for two motivations: to obtaining nottoo-big data to process during the experiments (more manageable project) and to work in a limit condition.

The data acquisition was performed in a target-less mode, and the scan alignment was carried out with a cloud-to-cloud registration (based on an Iterative Closest Point -ICPalgorithm) in the Cyclone REGISTER 360 software, previously removing the vegetation around the building. The cloud-to-cloud registration has a final medium group error of $4 \mathrm{~mm}$ (the maximum value is $7 \mathrm{~mm}$ for one pair of scans) with a medium overlap among the scan of about $40 \%$. The final aligned point model allows extracting the 3D coordinates of recognizable architectural features useful to scale and reference the photogrammetric project.

The research aims to evaluate the integration of point clouds from various sensors using the Structure-from-Motion (SfM) software Agisoft Metashape Professional [4]. In addition to the alignment (internal/external orientation) and the adjustment of the object coordinates (sparse point cloud), it allows the dense point cloud generation, by semi-global matching, the surfaces meshing and the true ortho-photos extraction. The innovative aspect of the procedure presented is the direct importing of the TLS point model into the photogrammetric project.

In particular, three different integration methods were analysed and evaluated (fig. 4).

A) The estimation of the translation, rotation and scale factor values using a self-calibrating bundle adjustment by including the Ground Control Point (GCPs). B) The integration of 
Fig. 4. Tests for datasets integration. Top view of the photogrammetric project: A) project.A) TLS cloud TIS pano TLS panoramic images (spheres) integration; C) TLS clouds aligned with ICP.

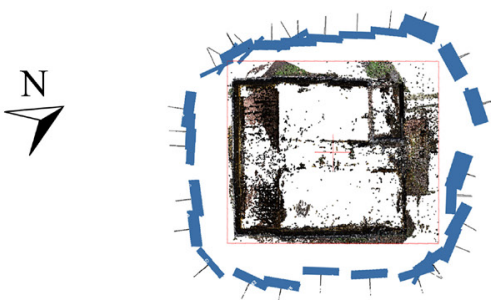

Test A
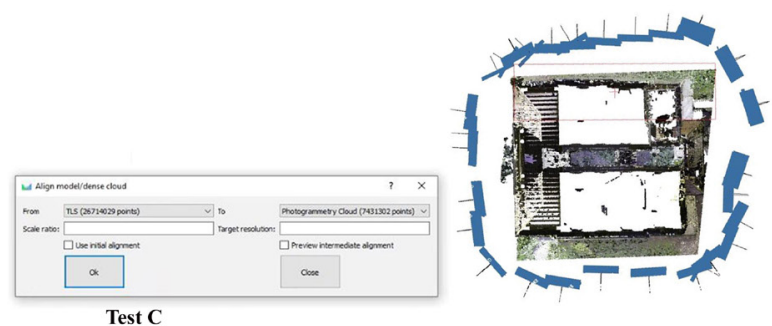

TLS Point Cloud

Test B

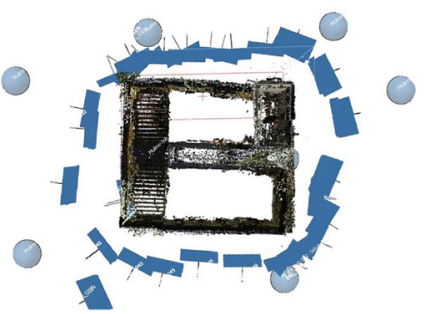

- Photogrammetry Point Cloud

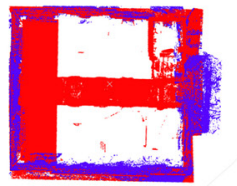

TLS data into the photogrammetric workflow of the Metashape project using the spherical panoramas captured by the laser scanner in the single stations. C) The use of a Python script (Metashape uses Python 3 as a scripting engine) to align independently a photogrammetric dense point cloud and a TLS point model (with a good overlap) through a classic ICP procedure.

Test A has followed a standard photogrammetric pipeline for the alignment step. The used GCPs were measured on natural architectural points directly from the TLS final model aligned in Cyclone Register 360. For the self-calibrating bundle adjustment calculation, 16 GCPs were included (4 for each faced), with an estimated RMSE of 3.2 $\mathrm{cm}$. The two point clouds are in the same local reference system and can be merged for subsequent elaborations (polygonal model generation, textured mesh creation and ortho-photo extraction).

In test B, the integration of active and passive sensor datasets is accomplished with a different approach. The spherical panoramas captured by the single laser scanners stations are imported and processed in the same Metashape project used for the close-range photogrammetric acquisitions. Therefore, first of all, the conversion of structured laser scanning data from raw to files format supported by the software (E57 or PTS) is required. The software uses the standard photogrammetric image matching procedure to register the photos and laser scanner panoramas in the same chunk.

The corresponding points between images and laser scans are identified during the images alignment step. The tie points found are used to triangulate the cameras positions and the laser scanner locations in the same reference system during the bundle adjustment. With this procedure, the alignment of TLS scans is done by implementing Structure from Motion algorithms between the laser panoramic images; consequently, the alignment accuracy calculated in TLS software processing is invalidated.

If the TLS scans registration is reliable and precise, it is possible to preserve its alignment and avoid the panoramas and photos image matching procedure. In this case, it is recommended to align the photogrammetric images first and then import the laser spherical panoramas in the same chunk and, eventually to run a specific Python script [5]. The photos exterior orientation and the laser scanner data must be in the same reference system to be correctly processed together.

For our analysis, we prefer the second pipeline that uses the TLS orientation as a reference because we have obtained a more efficient alignment between the two datasets. In particular, we used the same GCPs coordinates from the test ATLS cloud.

Finally test C, the aligned TLS cloud (not the single scans) is directly imported within the photogrammetric project to optimise the photogrammetric cloud through an ICP procedure. To speed up the procedure, as in tests $A$ and $B$, the two models are 
aligned in the same reference system using the selected GCPs coordinates. After running the Python script, the automatic procedure uses an open-source library [6] that that supports data structures and algorithms in both $\mathrm{C}++$ and Python for software with 3D data.

Fig. 5. Comparison between the TLS cloud and the point models derived by the $A, B$ and C tests.
Fig. 6. Confidence Map, the colour define the number of contributing combined depth maps for each point of the dense cloud.
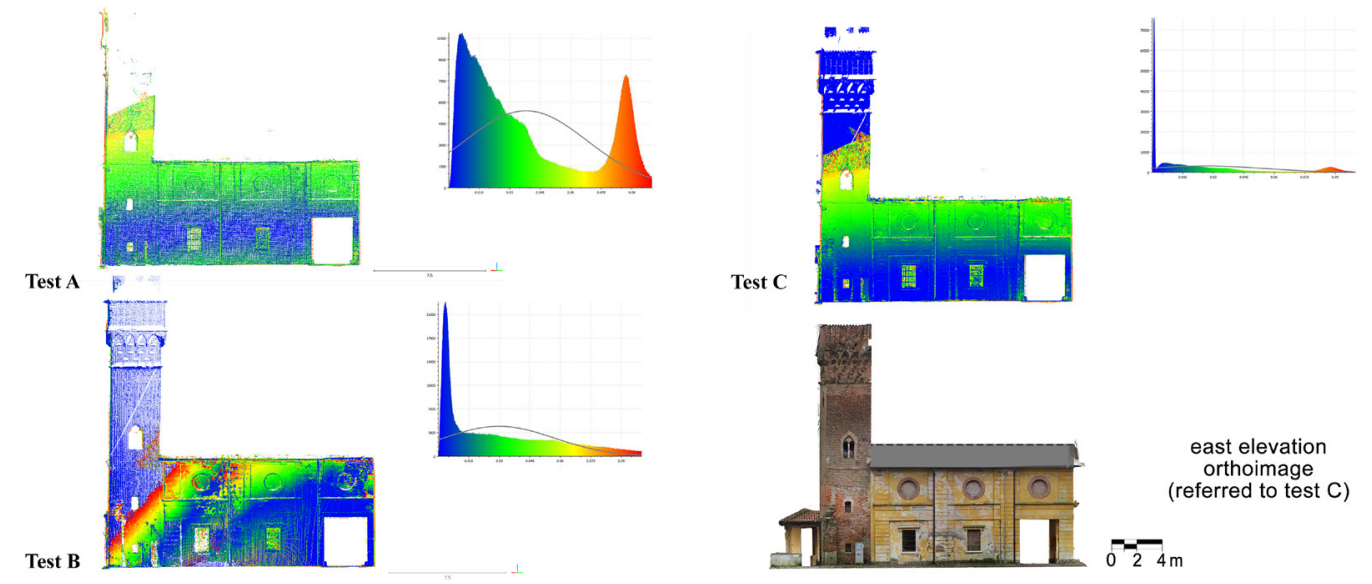

\section{Results analysis}

The first analysis developed is related to the direct comparison [7] between the laser scanner point cloud and the point model derived by the A, B and C tests; in general, all the comparisons computed use the finalTLS final point cloud as model reference.

For the comparison representation, we chose the elevation with the tower (north elevation of the mill) that introduces well-known difficulties related to the height. In figure 5, plotting the distances on a common scale of $0-10 \mathrm{~cm}$, it can be observed that test $\mathrm{A}$ output presents a wider distribution of distances, unlike the distributions of tests $B$ and $C$ that present a peak for the cloud to cloud distances lower than $5 \mathrm{~mm}$.

Therefore, the roto-translation executed using homologous points, also subsequently computed as GCPs in the bundle adjustment procedure too, produces more significant deviations (test A). These deviations also increase in height, as the distance of the 3D point from the TLS station and the photogrammetric shots increases. This tendency can also be observed for test $\mathrm{B}$ and $\mathrm{C}$.

Test $B$, with the insertion of the spherical images from the TLS, presents a map of deviations typical of a misalignment; probably, the panoramas produce an incorrect alignment for the

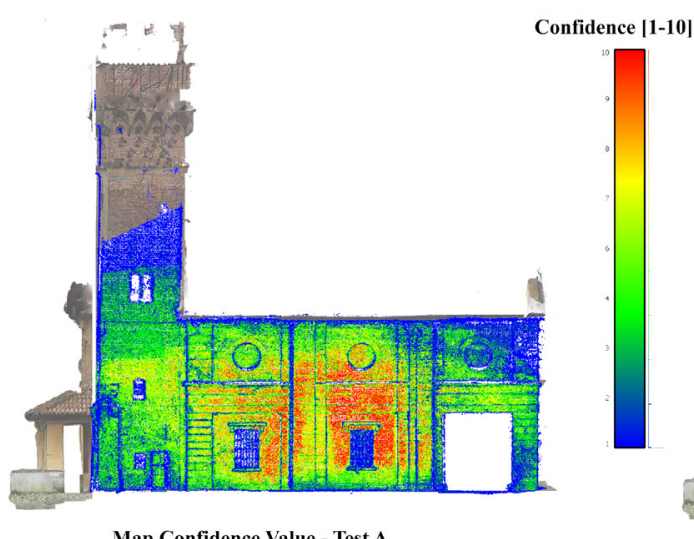

Map Confidence Value - Test A

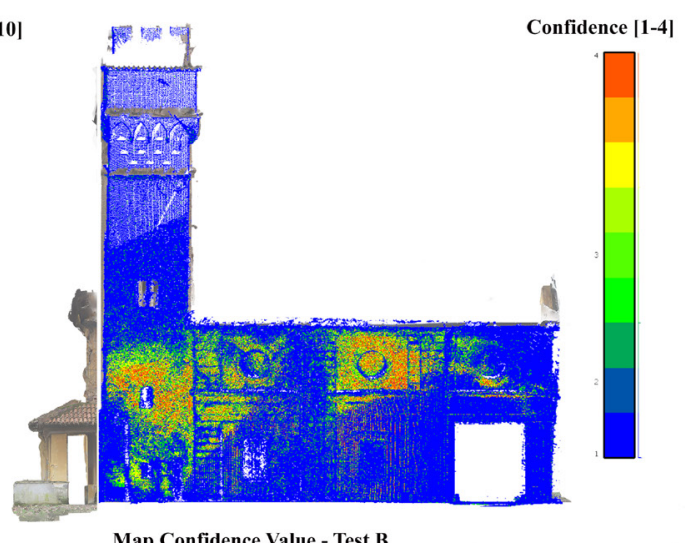

Map Confidence Value - Test B 
3D point projections. For this test, we observed a correlation between the cloud to cloud deviations and the 'confidence' value, calculated in Metashape; this parameter depends on how many depth maps have been used to generate the given 3D point (fig. 6). The incorrect positioning of the spherical images in $3 \mathrm{D}$ space also produces a false projection using the depth maps in the Dense Cloud.

Test $C$ is the test with the lowest peak and mean deviation compared to the other tests. As already observed in other studies, the positioning of the point clouds in the same reference system speeded up the process that was completed in a few iterations, due to the calculation of ICPs.

\section{Conclusion}

This paper presents the first results about integrating the active and passive sensors dataset applied to a small architectural scale case study, the Mulino del Cantone. The main objective was to test different procedures for the alignment and integration ofTLS and photogrammetric point clouds and to provide a first metric evaluation.

The procedure highlights two distinct advantages. Two systems can be combined to complete a 3D survey fastest and most efficient way. Laser scanning can be used to measure complex geometries and interior spaces (with more light problems). On the contrary Photogrammetry can be used for exteriors, especially if there is the possibility to acquire aerial images and produce effective ortho-images of the elevations [Russo 20।4; Achille 20 I; Repola 2019]. There are also cases in which it would be preferable the opposite. For example, if the building interior is frescoed and/or the exterior is in a built-up area with very narrow streets where cannot use a drone. In such a situation, as in the mill tower, the integration with TLS data also makes it possible to measure and represent the highest areas that are difficult to detect from a terrestrial photogrammetric acquisition (fig. 7).

Among the various tests, the implementation of an ICP algorithm (test C) turns out to be the procedure that optimizes the distances between point clouds.

The add-in the SfM workflow of the panoramic images acquired by TLS, together with terrestrial (or UAV) photos, can allow the integration of point clouds and subsequent merge, projecting from the depth maps (of the spherical and photogrammetric images) the 3D points for a dense cloud generation. In this case (test B), the accuracy of the integration is slightly lower. Still, it is a quick solution, especially when the interior is measured with TLS (generally for lack of light and to reduce acquisition times) while the exterior with photogrammetry. There must always be a portion with good overlap between the two surveys. Anyhow, the crucial requirements for a correct dataset integration are good overlaps between the point clouds and an adequate number of clearly visible control points in both. Further experiments are planned for the future; drone images and a more extensive network of laser stations (including the interiors) are expected to be included. Furthermore, we want to verify more SfM programs with the same dataset to compare pipelines and results.
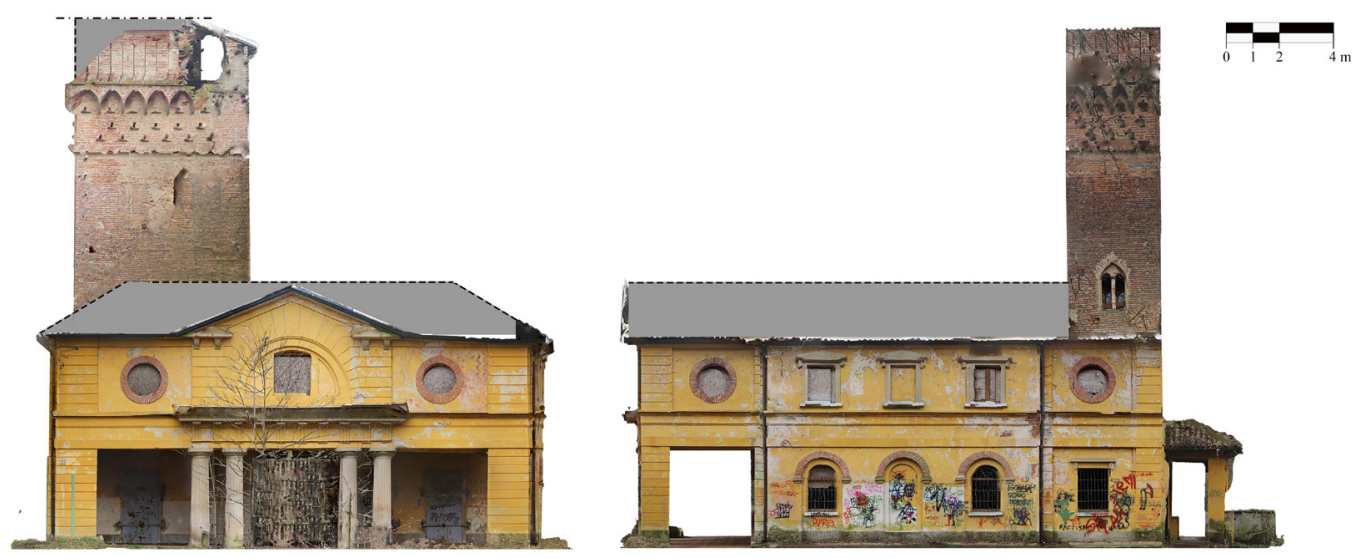


\section{Notes}

[I] The medieval turret is probably the only remain of the ancient protective front of Monza, connected with the nearby Villa Mirabello pre-existing structures. <https://it.wikipedia.org/wiki/Mulino_del_Cantone> (accessed 202I, February 26).

[2] Full-Frame sensor CMOS, 6240×4I60 px, pixel size of $5.75 \mu \mathrm{m}$.

[3] Technical specs: measuring rate up to 2 million points per second, operating range of 0,5- $130 \mathrm{~m}$, a scanning FOV of $360^{\circ}$ (horizontal rotating base) $\times 300^{\circ}$ (vertical rotating mirror), and estimated noise range of $4 \mathrm{~mm}$ at $10 \mathrm{~m}$.

[4]Version 1.7.1 in which tools to integrate and manage laser data have recently been included.

[5] <https://github.com/agisoft-Ilc/metashape-scripts/blob/master/src/quick_layout.py> (accessed 202I, February 26).

[6]. Open3D is released as open-source under the permissive MIT license and is available at <http://www.open3d.org> (accessed 2021, February 26).

[7] Function Cloud/Cloud-Distance in the open-source software CloudCompare. <https://www.danielgm.net/cc/> (accessed 2021, February 26).

\section{References}

Achille C. et al. (20 I5). UAV-Based Photogrammetry and Integrated Technologies for Architectural Applications - Methodological Strategies for the After-Quake Survey of Vertical Structures in Mantua (Italy). In Sensors, n. I 5/7, pp. I5520- I5539.

Adamopoulos E., (2017). Multi-sensor documentation of metric and qualitative information of historic stone structures. In Int. Arch. Photogramm. Remote Sens. Spatial Inf. Sci, n. IV-2/W2, pp. I-8.

Barba S. et al. (2019). Integration of active sensors for geometric analysis of the chapel of the Holy Shroud. In Int. Arch. Photogramm. Remote Sens. Spatial Inf. Sci., n. XLII-2MI 5, pp. I49-I56.

Beraldin J.A. (2004). Integration of laser scanning and close-range photogrammetry - The last decade and beyond. In AA.VV. Proceedings of the XXth ISPRS Congress, vol. 35, pp. I2-23.

Fassi F. (2007). 3D modeling of complex architecture integrating different techniques - a critical overview. In Int. Arch. Photogramm. Remote Sens. Spatial Inf. Sci, n. 36, pp.?????

Fassi F., Achille C., Fregonese L. (201 I). Surveying and modelling the main spire of Milan Cathedral using multiple data sources. In The Photogrammetric Record, n. 26, pp. 462-487.

Florio R. et al. (2020). Architettura archeologia per il rilievo integrato, il caso esemplare di Cuma: le Terme del Foro. In Arena A. et al. (a cura di), Connettere. Un disegno per annodare e tessere. Atti del $42^{\circ}$ Convegno Internazionale dei Docenti delle Discipline della Rappresentazione/Connecting. Drawing for weaving relationships. Proceedings of the 42th International Conference of Representation Disciplines Teachers, pp. 2 182-2203. Milano: FrancoAngeli.

Galli M. et al. (2019). Rappresentare il visibile e conoscere il non visibile: studi sulla Basilica lulia al Foro Romano. In Belardi P. (a cura di), Riflessioni l'Arte del Disegno/ll Disegno dell'Arte. Atti del $41^{\circ}$ convegno internazionale dei docenti delle discipline della rappresentazione congresso della Unione Italiana per il Disegno. Roma: Gangemi, pp. 667-674.

Hassan A.T., Fritsch D. (2019). Integration of Laser Scanning and Photogrammetry in 3D/4D Cultural Heritage Preservation - A Review. In International Journal of Applied Science and Technology, n. 9/4, pp. 76-91.

Higgins S. (June 14, 2018). Leica's RTC 360 lidar scanner registers your point clouds automatically, in real time, in the field. In SPAR3D. <https://www.spar3d.com/news/lidar/leicas-rtc360-lidar-scanner-registers-your-point-clouds-automatically-in-realtime-in-the-field/> (accessed 2021, February 26).

Luhmann T. (2019). Combination of Terrestrial Laserscanning, Uav and Close-Range Photogrammetry for 3D Reconstruction of Complex Churches in Georgia. In Int. Arch. Photogramm. Remote Sens. Spatial Inf. Sci., n. XLII-2M I I, pp. 753-76I.

Pelissetti L. S. (2009). Il parco di Monza. Itinerari storico-naturalistici. Missaglia (LC): Bellavite.

Remondino, F. (20II). Heritage Recording and 3D Modeling with Photogrammetry and 3D Scanning. In Remote Sensing, n. 3/6, pp. $1104-1138$.

Repola L. (2019). La rappresentazione quale specchio del reale: le nuove tecnologie a servizio della conoscenza per la documentazione di ambienti complessi. In Belardi P. (a cura di). Riflessioni l'Arte del Disegno. Atti del $41^{\circ}$ convegno internazionale dei docenti delle discipline della rappresentazione congresso della Unione Italiana per il Disegno. Roma: Gangemi, pp. $96 \mid-968$.

Russo M., Manfredini A. M. (20I4). Metodiche integrate di rilievo 3D per l'analisi di architetture complesse. II caso dell'abbazia di Pomposa. In Giandebiaggi P.,Vernizzi C. (a cura di). Italian Survey \& International Experience. $36^{\circ}$ Convegno Internazionale dei Docenti della Rappresentazione. Roma: Gangemi, pp. 989-998. 


\section{Website}

Agisoft Helpdesk Portal, 8/2/2021.Terrestrial laser scanning data processing. <https://agisoft.freshdesk.com/support/solutions/ articles/3 I000 I59 I0 I-terrestrial-laser-scanning-data-processing> (accessed 202I, February 26).

II Molino del Cantone (1899). <https://arengario.net/nelp/cartp08.html> (accessed 2021, February 26).

La chiusa del Cantone. <https://arengario.net/nelp/cartp24.html> (accessed 2021, February 26).

SIRBeC scheda ARL - MI230-00I02

<http://www.lombardiabeniculturali.it/architetture/schede/MI230-00102/> (accessed 2021, February 26).

\section{Authors}

Fausta Fiorillo, Politecnico di Milano, fausta.fiorillo@polimi.it

Marco Limongiello, Università degli Studi di Salerno, mlimongiello@unisa.it

Cecilia Bolognesi, Politecnico di Milano, cecilia.bolognesi@polimi.it

To cite this chapter. Fiorillo Fausta, Limongiello Marco, Bolognesi Cecilia (2021). Integrazione dei dati acquisiti con sistemi image-based e rangebased per una rappresentazione 3D efficiente/lmage-Based and Range-Based Dataset Integration for an Efficient 3D Representation. In Arena A., Arena M., Mediati D., Raffa P. (a cura di). Connettere. Un disegno per annodare e tessere. Linguaggi Distanze Tecnologie. Atti del $42^{\circ}$ Convegno Internazionale dei Docenti delle Discipline della Rappresentazione/Connecting. Drawing for weaving relationship. Languages Distances Technologies. Proceedings of the 42 th International Conference of Representation Disciplines Teachers. Milano: FrancoAngeli, pp. $2319-2336$. 